\title{
The role of glucagon-like peptide 1 in glucose homeostasis and in other aspects of human physiology
}

\author{
Edward Franek ${ }^{1,2}$, Grzegorz Gajos ${ }^{3,4}$, Janusz Gumprecht ${ }^{5}$, Adam Krętowski ${ }^{6}$, \\ Barbara Zahorska-Markiewicz ${ }^{7}$, Maciej T. Małecki ${ }^{8}$ \\ 1 Department of Internal Diseases, Endocrinology and Diabetology, Central Clinical Hospital, Ministry of the Interior and Administration, Warszawa, Poland \\ 2 Endocrinology Unit, Mossakowski Medical Research Centre, Polish Academy of Sciences, Warszawa, Poland \\ 3 Institute of Cardiology, Jagiellonian University School of Medicine, Kraków, Poland \\ 4 John Paul II Hospital, Kraków, Poland \\ 5 Department of Internal Diseases, Diabetology and Nephrology, Medical University of Silesia, Zabrze, Poland \\ 6 Department of Endocrinology, Diabetology and Internal Diseases, Medical University of Bialystok, Białystok, Poland \\ 7 WAGA Metabolic Diseases Clinic, Katowice, Poland \\ 8 Department of Metabolic Diseases, Jagiellonian University School of Medicine, Kraków, Poland
}

\section{KEY WORDS}

GLP-1, incretin axis, intestinal hormones, insulin secretion
Correspondence to:

Prof. Maciej T. Małecki, MD, PhD, Katedra i Klinika Chorób Metabolicznych, Uniwersytet Jagielloński, Collegium Medicum ul. Kopernika 15,

31-501 Kraków, Poland phone: + 48-12-424-83-01 fax: +48-12-421-97-86, e-mail: mmalecki@cm-uj.krakow.pl Received: September 7, 2009 Revision accepted: September 19, 2009. Conflict of interest: none declared Pol Arch Med Wewn. 2009; 119 (11): 743-751 Translated by Winston Nyamogo, MD Copyright by Medycyna Praktyczna, Kraków 2009

\section{ABSTRACT}

This paper reviews the structure, function, and pathophysiology of glucagon-like peptide 1 (GLP-1). It describes the physiology and pathophysiology of the incretin axis, of which GLP-1 is a component, as well as the biosynthesis, secretion, activity, and degradation of this intestinal hormone. Effects of GLP-1 on the endocrine function of the pancreas, cardiovascular system, central nervous system, and on water-electrolyte balance have been also presented.

The incretin axis Insulin, a hormone secreted by the pancreatic $\beta$ cells, is a key regulator of carbohydrate and lipid metabolism. One of the numerous biological functions of insulin is the reduction of the blood glucose concentration. Under physiological conditions, insulin secretion is potentiated in response to a rise in blood glucose levels. However, not every hyperglycemic stimulus up-regulates insulin secretion to an identical extent. It appears that oral administration of glucose is a more potent secretory stimulus than its intravenous infusion. ${ }^{1}$ This phenomenon indicates the existence of an additional $\beta$-cell stimulating mechanism, which is linked to the gastrointestinal tract and is independent of blood glucose levels.

This observation gave rise to the "incretin effect" concept, i.e., stimulation of insulin secretion as a response to food consumption before blood glucose levels rise. The first substance which fit the description of incretin was glucose-dependent insulinotropic polypeptide (GIP), formerly known as gastric inhibitory polypeptide. ${ }^{2}$
Another intestinal hormone with the incretin effect is the glucagon-like peptide 1 (GLP-1). Its effect on carbohydrate metabolism results from direct stimulation of insulin secretion, increase in insulin gene expression, trophic effect on $\beta$ cells, prevention of their apoptosis, and inhibition of glucagon secretion. Furthermore, this hormone increases the feeling of satiety and inhibits emptying of the stomach..$^{3,4}$

GLP-1 structure GLP-1 is a product of the same gene which encodes glucagon, a fact that was proven after cloning it. ${ }^{5}$ It is secreted primarily by $\mathrm{L}$ cells located in the duodenum, jejunum, ileum, and the colon. It is produced in significantly smaller amounts by the pancreas and hypothalamus. ${ }^{6}$ Its main biologically active form is GLP-1(7-36). Other forms are GLP-1(7-37), as well as GLP-1(1-36) and GLP-1(1-37), which are secreted mainly by the pancreas. The active form is a result of enzymatic processing of preproglucagon into proglucagon, from which major proglucagon fragment is then detached. This transformation is 
catalyzed by protein convertase PC $1 / 3 .^{7}$ The next precursor is tGLP-1, which is subsequently transformed into GLP-1. ${ }^{8}$ This peptidein turn undergoes amidation, catalyzed by peptidylglycine $\alpha$-monooxygenase as well as peptidylamide glucan liase. ${ }^{9}$ Eventually, the mature form of GLP-1 consists of 31 amino acid residues.

GLP-1 metabolism GLP-1 is secreted in response to food intake and reaches its peak concentration in blood plasma within 10 min of consumption. ${ }^{10}$ Apart from food components, glucose, and fatty acids, other stimulants of GLP-1 secretion include GIP, gastrin-releasing polypeptide (GRP), and impulses transmitted by the vagus nerve through acetylcholine. ${ }^{11}$ Once secreted into the circulatory system, GLP-1 is broken down within minutes, mainly by the enzyme dipeptidyl peptidase-4 (DPP-4). ${ }^{12}$ Another, less important mechanism of elimination is renal clearance. ${ }^{13}$ As a result of very efficient elimination mechanisms, especially DPP-4 activity, the concentration of the active GLP-1 form constitutes only $20 \%$ of its overall concentration. ${ }^{14}$ DPP-4, also known as CD-26, is a transmembrane glycoprotein, which forms a homodimer with a molecular mass of about $250 \mathrm{kDa} .{ }^{15}$ Each subunit consists of a large extracellular domain with proteolytic qualities, a single transmembrane chain, and a small intracellular fragment. ${ }^{16}$ This enzyme is expressed on the surface of numerous cells, such as lymphocytes, endothelial cells, enterocytes, in the liver, lungs, kidneys, and others. ${ }^{17}$ Under the influence of DPP-4, GLP-1 is transformed into GLP-1(9-36), GLP-1(7-35), and GLP-1(7-34). ${ }^{18}$ They do not display incretin activity, and they may have an antagonistic effect on GLP-1(7-36). ${ }^{19}$ DPP-4 breaks down not only GLP-1, but also neuropeptide Y, peptide YY, GIP, growth hormone-releasing hormone, tissue hormones, and chemokines. ${ }^{20}$

The GLP-1 receptor GLP-1 binds with a specific receptor, GLP-1 receptor (GLP-1R), which shows a structural similarity to the glucagon receptor. ${ }^{21}$ GLP-1R has the classic structure of G-protein-coupled and adenylate-cyclase-coupled receptors, which penetrate the cell membrane 7 times. The receptor's molecular mass is about $65 \mathrm{kDa}$. Stimulation of the receptor results in a rise in intracellular cyclic adenosine monophospate (cAMP) and calcium concentration, which in $\beta$ cells is a signal for exocytosis of previously synthesized insulin. ${ }^{22}$ In addition, activation of protein kinase A potentiates insulin biosynthesis, modifies gene expression, and has a trophic as well as promitotic effect on $\beta$ cells. ${ }^{23}$ Besides insulin-producing cells, GLP-1R is also expressed in $\alpha$ cells, in the brain, central nervous system, gastrointestinal tract, kidneys, liver, and lungs. ${ }^{24}$ Such prevalence of GLP-1R in peripheral tissues suggests pleiotropic activity of this intestinal hormone.

The effect of GLP-1 and incretin mimetics on $\beta$ cells Numerous experiments indicate that native GLP-1 increases $\beta$-cell mass in animals with experimental diabetes (chemically or surgically induced) by stimulating their proliferation, ${ }^{25}$ neogenesis of pancreatic islets from precursor cells, ${ }^{26}$ and by inhibiting $\beta$-cell apoptosis. ${ }^{27} \mathrm{~A}$ similar effect is observed in animal models, as well as in in-vitro studies on long-acting incretin mimetics: exendin $-4^{28}$ and liraglutide. ${ }^{29,30}$ The mechanism of antiapoptotic effect produced by GLP-1 on $\beta$ cells is dependent on both the cAMP and phosphatidylinositol kinase pathways. ${ }^{31}$ It has been shown that activation as well as stimulation of inhibitor of apoptosis 2 and $\mathrm{Bcl}-2$ antiapoptotic gene expression occurs during this process. ${ }^{32}$

In recent research, however, no significant effect of GLP-1 (10 $\mu \mathrm{g} / \mathrm{kg}$ or $100 \mu \mathrm{g} / \mathrm{kg}$ was administered intraperitoneally [IP] from the third to sixth day of the disease) on the mass of $\beta$ cells in most of nonobese diabetic (NOD) mice with autoimmune diabetes, when GLP-1 was administered as the only therapeutic agent. ${ }^{33}$ In this experiment, normoglycemia combined with a decrease in anti-insulin antibody titer in the fifth week after GLP-1 therapy was obtained in 4 out of 14 animals, while all NOD mice (7 out 7 ) which received placebo injections (PBS solution) were characterized by elevated glycemia values and significantly reduced $\beta$-cell mass. However, when GLP-1 (100 $\mu \mathrm{g} / \mathrm{kg} 2 \times /$ day IP) was administered together with gastrin $(1.5 \mu \mathrm{g} / \mathrm{kg} 2 \times /$ day IP), a return to normoglycemia was observed in all NOD mice. At the same time, an increase in mass and a decrease in the extent of $\beta$-cell apoptosis were observed, alongside an increase in the number of precursor cells staining for insulin presence within the pancreatic ducts. ${ }^{33}$ Of note, combined therapy of GLP-1 and gastrin had an inhibitory effect on autoimmune process directed against the antigens of pancreatic islet $\beta$ cells. In those animals, a decline in anti-insulin antibodies was observed, and the transfer of "immunologically modified" monocytes harvested from their spleens prevented disease development in the recipients, i.e. mice predisposed to autoimmune diabetes. ${ }^{33}$

Current observations concerning the effect of high (supraphysiological) GLP-1 concentrations, as well as chronic stimulation by GLP-1 (and its analogues) on pancreatic duct $\beta$ cells in humans are not unequivocal. ${ }^{34-36}$ On one hand, researchers have reported cases of nesidioblastosis (hypertrophy and hyperplasia of pancreatic islet $\beta$ cells with accompanying postprandial simultaneous hypoglycemia) in patients who had undergone bariatric surgery (especially the Roux-en Y operation), ${ }^{37,38}$ which is linked to GLP-1 hypersecretion. It was proven that in healthy people GLP-1 concentration does not exceed $20 \mathrm{pmol} / 1$, while in patients who had undergone bariatric surgery, GLP-1 values exceed $100 \mathrm{pmol} / \mathrm{l}$, accompanied by a doubling of an insulin concentration 30 min after a standard meal. ${ }^{39}$

So far, however, no intensification in time of the effect of increased GLP-1 secretion on $\beta$ cells has been observed - indeed, no significant 
TABLE Mechanisms of GLP-1 activity

\section{Mechanisms of GLP-1 activity}

\section{pancreas}

stimulates glucose-dependent insulin secretion

potentiates $\beta$-cell response to glucose

potentiates transcription of insulin-encoding gene, increases mRNA stability and biosynthesis

stimulates $\beta$-cell neogenesis and proliferation

inhibits $\beta$-cell apoptosis

inhibits glucagon secretion

stimulates somatostatin secretion

gastrointestinal tract

inhibits gastric emptying

inhibits secretion of gastric juices

central nervous system

inhibits food and water intake

stimulates satiety, affects loss of body weight

has neurotrophic and neuroprotective activity

cardiovascular system

vasodilatory activity via an endothelium-dependent mechanism

cardioprotective activity during ischemic-reperfusive injury

inhibits cardiomyocyte apoptosis after experimental ischemia

differences in insulin secretion were found between patients at different post-bariatric operation stages (9-15 months vs $21-30$ months $v s>36$ months). ${ }^{39}$ In case of a clinically significant GLP-1 effect on $\beta$ cell hypertrophy/hyperplasia, one may expect a progressive potentiation of insulin production/secretion.

Initial reports concerning 4 patients who underwent pancreatic islet transplantation using the Edmonton Protocol suggest that administration of etanercept and exenatide may improve survival and function of transplanted $\beta$ cells (higher insulin values in the first and second phases of secretion) during 18 months of follow-up. ${ }^{40}$

In another study, which comprised 5 patients following islet transplantation and 6 patients who had undergone pancreas transplantation, it was demonstrated that during a single GLP-1 intravenous infusion, increased insulin secretion resulted from increased release of secretory granules, including immature granules (increase in proinsulin secretion). ${ }^{41}$

Current clinical observations therefore indicate the need for further research on the effect of pharmacological concentrations of GLP-1 and its long-acting analogues on $\beta$-cell proliferation during their chronic administration in vivo. ${ }^{42}$

The effect of GLP-1 on the central nervous system and on body mass The main production and secretion site for GLP-1 are the intestinal endocrine L cells. Their stimulation, which begins immediately after food consumption, is regulated in part by the nervous system via the cholinergic system and M1 and M2 receptors; adrenergic stimulation also plays a certain role. GLP-1Rs are present in the central nervous system, where GLP-1 is also produced. ${ }^{43}$
GLP-1 has neurotrophic and neuroprotective properties. As human life span becomes longer, there is an increase in the number of people with such diseases as Alzheimer's or Parkinson's characterized by neurodegenerative lesions dependent on age. In Alzheimer's disease, lesions are caused by a toxic protein, amyloid $\beta(A \beta)$, excess glutamine, and disruption of calcium homeostasis. While binding with the GLP-1R, GLP-1 displays neurotrophic properties, protects against excess glutamine, ${ }^{44}$ and reduces the amount of $A \beta{ }^{45}$ This creates a possibility for the use of GLP-1 in the treatment of Alzheimer's disease. ${ }^{46}$ During research on GLP-1's effect on calcium canal regulation in the hippocampus neurons, a decrease in glutamine's toxic activity, reduced depolarization, and a higher cell survival rate were observed. ${ }^{47}$ In animals, GLP-1 constitutes a neuroprotective factor for pyridoxine-induced peripheral neuropathy. Hence, GLP-1 may prove useful in the treatment of diabetic neuropathy. ${ }^{48}$

A study on rats with the use of a floating platform showed a beneficial effect of GLP-1 on learning and spatial memory. Animals which had been treated with GLP-1 intracerebroventricularly, or which had genetically enhanced GLP-1R expression, more easily, and via a shorter route, found their way to the floating platform. ${ }^{49}$

By affecting the central nervous system, GLP-1 causes a rise in temperature along with secretion of pituitary hormones including thyroid stimulating hormone, luteinizing hormone, and vasopressin..$^{50}$ In mice with mutation of the receptor (knockout GLP-1R-/-), the main function of the hypothalamic-pituitary-adrenal axis is preserved, while there is an increase in corticosteroid concentrations in response to stress. ${ }^{51}$ GLP-1 regulates appetite. Administered intracerebroventricularly to rats, it reduced food intake by acting on the GLP-1Rs in the hypothalamus. ${ }^{52}$ GLP-1 also reduces food intake through its central effect on the hypothalamus, which increases satiety and delays emptying of the stomach. ${ }^{53}$ Peripheral GLP-1Rs delay stomach emptying, trigger the end of feeding, and cause satiety through the vagus nerve. Vagotomy reduced the anorectic effect of GLP-1, thus indicating the significance of this anorectic signal transmitted to the hypothalamus. ${ }^{54}$

The effect of GLP-1 on food intake was studied in rats under various laboratory conditions. The stress that accompanied the animals when transferred to clean cages reduced the anorectic effect of GLP-1. ${ }^{55}$

GLP-1 administered intracerebroventricularly to chicks caused a decrease in food intake, and although it did not affect energy expenditure, calculated on the basis of oxygen intake and carbon dioxide production, this decrease in the RQ ratio indicated a change in the proportion of energy substrates used from carbohydrates to fats. ${ }^{56}$ The effect of the lower parts of the brain stem and the adrenergic system on an increase in energy expenditure was observed after intravenous 
FIGURE The most important effects of GLP-1 activity on the cardiovascular system Abbreviations:

DPP-4 - dipeptidyl peptidase-4, GLUT-1 glucose transporter 1 , LVEDP - left ventricular end-diastolic pressure, LVEF - left ventricular ejection fraction, MAP mitogen-activated protein, NO - nitric oxide, PAI-1 plasminogen activator inhibitor-1, RISK reperfusion injury salvage kinases, TNF-atumor necrosis factor a
GLP-1

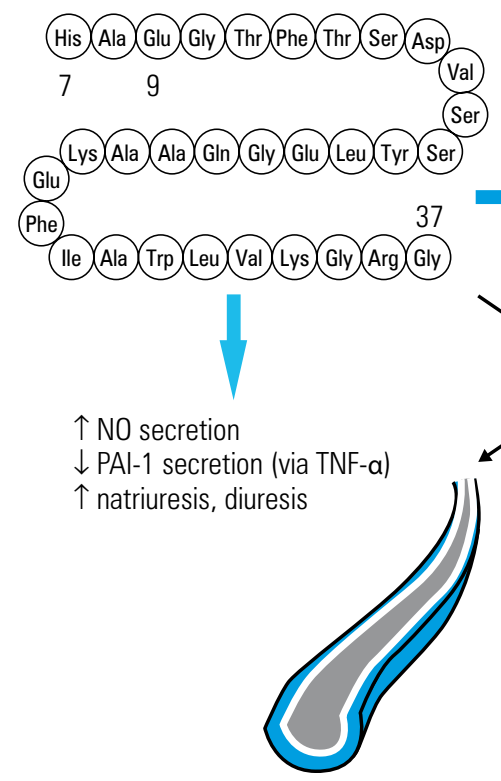

- reduction of systemic vascular resistance
- transient ischemia: ischemic preconditioning

- myocardial infarction: reduction of the extent of reperfusive damage

- coronary insufficiency: improvement of cardiac output, as well as LVEF, reduction of LVED administration of GLP-1. ${ }^{57}$ GLP-1's significance for maintaining glucose homeostasis is attributed to regulation by potentiating insulin secretion by the pancreas. Cerebral GLP-1 affects systemic regulation of glucose concentration during hyperglycemia: glucose intake by the muscles is inhibited, while storage of glycogen in the liver is increased. ${ }^{58}$ This incretin-independent effect of GLP-1 on hepatic and muscular regulation of glucose intake was confirmed in a study on mice with GLP-1R-/- and GLP-1R+/+ receptors and the use of a hyperinsulinemic clamp and physical exercise. ${ }^{59}$ GLP-1-mediated effect on adipose tissue is characterized by stimulation of glycogenesis and inhibition of lipogenesis.

Intracerebroventricular GLP-1 administration reduced fat storage in white adipose tissue in mice. This effect was independent of food intake, dependent on adrenergic activity, and was less pronounced in obese mice. ${ }^{60}$

In order to establish whether stimulation of incretin secretion occurred via a pathway similar to stimulation of sweet taste receptors in the oral cavity, a comparison of GLP-1 secretion after administration of glucose and various sweeteners, such as saccharine, was performed. Unlike glucose, sweeteners did not affect GLP-1 concentration. ${ }^{61}$

In intestinal $\mathrm{L}$ cells, sweet taste receptors as well as the $G$ protein, gustducin, were identified, which indicates that local regulation exists in the intestines, in which the same $\mathrm{L}$ cells detect glucose and then secrete GLP-1. ${ }^{62}$

Both GLP-1 and peptide YY are secreted in the intestines by $\mathrm{L}$ cells. Their concentration in the blood rises after meals, and if administered peripherally, they inhibit food intake. Simultaneous administration of GLP-1 and peptide YY, both in mice and in humans, synergistically potentiated the inhibitory effect on food intake. ${ }^{63}$

Oral administration of glutamine effectively increased GLP-1 concentrations in lean subjects and in obese subjects without diabetes. The rise in GLP-1 concentration was least pronounced in obese diabetic individuals. At the same time, there was a rise in both insulin and glucagon concentrations. ${ }^{64}$

Stimulation of GLP-1 production depends on the type of food product. Quickly absorbed protein products, such as whey protein result in a stronger GLP-1 response than casein, ${ }^{65}$ which is slowly absorbed.

Intravenous administration of GLP-1 in humans enhances the feeling of satiety and fullness, and mitigates hunger and the desire to eat, as well as significantly reduces food intake. ${ }^{66}$ In both lean and obese patients, GLP-1 infusion reduced food intake by $727 \mathrm{~kJ}$ on average. Reduction of food intake was dependent on the dose and was larger in lean patients than in obese ones. A concentration of GLP-1 in the blood had an effect on hunger and satiety; however, it had no correlation with the magnitude of food intake. ${ }^{67}$

GLP-1's effect on inhibition of stomach emptying, potentiating fullness and satiety, as well as decreased food intake results in reduced body weight. This was illustrated using a subcutaneous GLP-1 infusion for 6 weeks and comparing GLP-1 infusion to that of physiological saline in patients with type 2 diabetes. ${ }^{68}$ 
Administration of GLP-1 for 6 weeks in form of continuous subcutaneous infusion or subcutaneous injections 4 times a day before meals led to a $15 \%$ reduction in food intake and loss of body mass. ${ }^{69}$

A role of GLP-1 in the pathogenesis of obesity has not been established to date. ${ }^{70}$ In most studies, reduced GLP-1 concentration was noted in obese subjects. ${ }^{71,72}$

Leptin is a long-acting signal in energy homeostasis, which gives information on the body's fat reserves; however, most hormones of the gastrointestinal tract are secreted shortly after food intake. ${ }^{73}$ Most hormones produced in the gastrointestinal tract, apart from ghrelin, have an anorectic effect which increases satiety. This stops feeding and promotes satiety, thus delaying the next meal. ${ }^{74}$ The role of gastrointestinal tract hormones in obesity and their role in reduction of body mass was better understood thanks to the effects obtained after bariatric surgery.

Currently, the most commonly applied surgical techniques in bariatry are:

1 restrictive operations which reduce food consumption, such as gastric banding

2 absorption-restricting operations, such as bilio-pancreatic bypass

3 operations combining restriction and reduction of absorption, such as bilio-pancreatic bypass with a duodenal switch, or distal gastric bypass.

The loss of body mass observed after these operations was initially solely attributed to food restriction due to reduced stomach volume or reduced absorption. It turned out, however, that reduced appetite was yet another factor which facilitated body mass reduction in patients who had undergone these operations. ${ }^{75}$ This mechanism may be caused by changes in the passage of food through the gastrointestinal tract and its effect on hormone secretion - an earlier increase in concentrations of glycemia-counteracting hormones, such as GLP-1, was found. ${ }^{76}$

Reduced fasting GLP-1 concentrations in the blood, observed after weight loss, may have an effect on increase in appetite and on a tendency to a commonly observed reiterated increase in body mass. ${ }^{77}$ The incretin axis constitutes a potentially important therapeutic target in the treatment of obesity. ${ }^{78,79}$

The effect of GLP-1 on ion equilibrium and the kidneys Towards the end of the 20th century, it was proven that glucagon administration in experimental animal model induced changes in glomerular filtration, diuresis, as well as electrolyte and urea excretion. ${ }^{80}$

GLP-1 also possesses at least part of these properties. It shows diuretic and natriuretic activity in both lean and obese subjects. Glomerular filtration in obese people decreases under the influence of GLP-1, while in lean people it does not change significantly. ${ }^{81,82}$ Of note is the fact that in experimental animals, GLP-1 increases glomerular filtration ${ }^{83}$ and potassium excretion. The latter phenomenon is not observed in humans. ${ }^{83}$

It is controversial what causes these differences. We cannot rule out that results of the studies in humans are erroneous due to flawed methodology. Another possible explanation is that in obese people in whom hyperfiltration occurs (or in whom one can expect hyperfiltration), GLP-1 acts differently, protecting the kidneys from additional increase in filtration after meals.

Regardless of the above-mentioned controversy, all available data indicate that GLP-1 (both in animals and in humans), has a natriuretic and diuretic effect. This may be of potentially great clinical significance because an increase of both sodium and urine excretion may have an antihypertensive effect. Both these effects may explain the drop in blood pressure observed after administration of GLP-1 in sodium-sensitive rats with hypertension, ${ }^{84}$ as well as after administration of GLP-1 analogues in humans. ${ }^{85}$ At the same time, in humans at least, GLP-1 seems not to have a negative effect on potassium equilibrium.

The effect of GLP-1 on the cardiovascular system Apart from the well-documented incretin effect of GLP-1, its role in the cardiovascular system also arouses interest. This is caused not only by numerous observations in experimental research with the use of incretin, but also by greater interest in the effect of potential antidiabetic drugs on the cardiovascular system. In the case of GLP-1, its effect on the cardiovascular system may include a direct effect on the cardiac muscle and the vascular system. This concerns both patients with type 2 diabetes and those without diabetes.

The first observations concerning GLP-1's vasodilatatory effect via an endothelium-dependent mechanism were made in the pulmonary artery's vascular bed. ${ }^{86}$ The possibility of improvement of endothelial function was confirmed in patients with diabetes and stable coronary disease. ${ }^{87}$ Recently it has been observed that a product of GLP-1(7-36) degradation by DPP-4, namely GLP-1(9-36), also has a vasodilatatory effect, and that this activity does not require the GLP-1R. ${ }^{88}$ In reference to its effect on the heart, GLP-1's cardioprotective properties under conditions of ischemia and reperfusion may depend on activation of intracellular defense mechanisms and modulation of cardiomyocyte metabolism. Experimental research on animals revealed that GLP-1 administration may reduce myocardial infarct size. ${ }^{89}$ In clinical research on patients with acute myocardial infarction, it was observed that administration of GLP-1 after reperfusion through direct coronaroplasty improves systolic function of the left ventricle. ${ }^{90}$ The mechanisms of this beneficial effect are currently investigated. It was shown that GLP-1 leads to kinase activation, on which the extent of reperfusive injury depends. ${ }^{89,91}$ This includes phosphatidyl inositol 3-kinase (PI3K) cascade, as well as extracellular 
regulated kinase. ${ }^{91}$ Under conditions of myocardial reperfusion damage, they are listed among reperfusion injury salvage kinases (RISK). ${ }^{91}$ Activation of the RISK pathway leads to translation of protective proteins, activation of antiapoptotic mechanisms, and prevents opening of megacanals. Under experimental conditions, Bose et al. proved that the mechanism of GLP-1's cardioprotective activity entails PI3K activation, ${ }^{89}$ followed by $\mathrm{p} 70$ s6K activation. ${ }^{91}$ The $\mathrm{p} 70$ s6K pathway regulates the translation and synthesis of proteins which are key to the growth and survival of cells in mammals. ${ }^{91}$

The human heart consumes a few kilograms of adenosine-5'-triphosphate daily, which is essential to sustain basic functions of the myocardium. Cardiac muscle in mammals has the capacity for aerobic metabolism of fats and carbohydrates. Under normal conditions, energy is obtained mainly from metabolism of free fatty acids. Under ischemic conditions, metabolism is shifted towards glucose consumption, which is more effective in terms of energy. ${ }^{92}$ Chronic hemodynamic load on the heart leads to reactivation of fetal genes and change of the dominant oxidation supplement in the cardiomyocytes to glucose. ${ }^{92,93}$ At the beginning, this adaptive activity is beneficial, but with time it leads to the development of insulin resistance in the myocardium. ${ }^{93}$ This leads to a loss of metabolic elasticity which is essential for the proper cardiac function, and leads to the development of cardiomyopathy. ${ }^{93}$ An example of a possible beneficial effect on cardiac metabolism is the use of free fatty acid oxidation inhibitors (partial fatty-acid oxidation), trimetazidine and ranolazine, in the treatment of coronary artery disease and chronic heart failure. ${ }^{92}$ For this reason, potential positive effects of GLP-1 in ischemia and coronary insufficiency are a subject of considerable interest.

In experimental animal models, it has been shown that GLP-1 administration during ischemia and reperfusion reduces accumulation of lactates and pyruvates in ischemic tissues. ${ }^{94}$ Studies on cultures of human myocytes demonstrated an improvement in glucose metabolism. ${ }^{95}$ The question remains whether metabolic effect observed after administration of GLP-1 could be linked to insulin's effect on the myocardium, or to the direct activity of GLP-1. ${ }^{94}$ Zhao et al. illustrated, in a model of isolated rat hearts, that GLP-1 increases glucose consumption almost 3-fold, and accelerates the restoration of myocardial function after episodes of ischemia in an alternate mechanism to insulin activity, which is independent of activation of protein kinase Akt- 1 , and translocation of insulin-regulated glucose transporter (GLUT)-4. ${ }^{96}$ This mechanism probably includes an increase of nitrous oxide production in the myocardium, increase in mitogen-activated protein p38 kinase activity, and translocation of GLUT- $1 .{ }^{96}$ In vivo studies in dogs with pacing-induced dilated cardiomyopathy has shown that GLP-1 infusion induces a substantial improvement of left ventricular function and increases glucose myocardial intake. ${ }^{97}$ In other studies, also on dogs with pacing-induced dilated cardiomyopathy, during euglycemic metabolic clamp, it was shown that not only GLP-1(7-36), but also GLP-1(9-36), a product of its degradation, have a similar beneficial effect on the heart. ${ }^{98}$ Furthermore, it has been demonstrated that some beneficial effects of GLP-1(7-36) administration also occur in mice which do not possess a receptor for this form of GLP- $1 .^{88}$ This may indicate that also GLP-1(9-36) is biologically active in the myocardium and in the blood vessels, and may have its receptor. ${ }^{88}$ It is important to explain these observations because administration of DPP-4-resistant GLP- 1 analogues and DPP-4 inhibitors would be devoid of part of the beneficial effects on the myocardium and the blood vessels. ${ }^{88,98}$

Recently, it has been proven for the first time that long-term infusion of GLP-1 extends survival time in obese, spontaneously hypertensive, heart failure-prone rats. ${ }^{99}$ GLP-1's activity in this experimental model of heart failure was linked to an improvement in contractility and in left ventricle output both in vitro and in vivo. It was also associated with higher glucose consumption and reduced cardiomyocyte apoptosis. ${ }^{99}$ Research on the effect of GLP-1 on apoptosis and glucose intake was conducted on models of isolated rat hearts. Reduction of apoptosis in the group treated with GLP-1 was linked to a decrease in caspase-3 activity in the myocardium. ${ }^{99}$ Similar, positive observations regarding myocardial function were made earlier in small groups of patients with chronic heart failure, ${ }^{100}$ and those who had undergone aorto-coronary bypass. ${ }^{101}$ These studies showed that patients without diabetes had similar benefits to those with diabetes. ${ }^{99-101}$ This again indicates that GLP-1 can directly act on the cardiovascular system, independently of glycemia control. The FIGURE summarizes the most important effects of GLP-1 activity on the cardiovascular system.

In summary, the incretin axis constitutes a promising target for therapeutic action in type 2 diabetes. GLP-1, the most important hormone of the incretin axis, demonstrates multidirectional activities, the most important of which have been summarized in the TABLE. Drugs associated with the incretin axis may potentially regenerate its impaired function, upregulate insulin secretion, positively affect body mass, appetite, blood pressure, and cardiovascular function. Our knowledge on how to fully exploit therapeutic possibilities of the incretin axis still incomplete, and the issue certainly requires further research.

\section{REFERENCES}

1 Elrick H, Stimmler L, Hlad CJ Jr, Aray Y. Plasma insulin response to oral and intravenous glucose administration. J Clin Endocrinol Metab. 1964; 24: 1076-1082.

2 Dupré J, Ross SA, Watson D, et al. Stimulation of insulin secretion by gastric inhibitory polypeptide in man. J Clin Endocrinol Metab. 1973; 37: $826-828$. 
3 Drucker DJ. Minireview: the glucagon-like peptides. Endocrinology. 2001; 142: 521-527

4 MacDonald PE, El-Kholy W, Riedel MJ, et al. The multiple actions of GLP-1 on the process of glucose-stimulated insulin secretion. Diabetes. 2002; 51 Suppl 3: S434-S442.

5 Bell GI, Santerre RF, Mullenbach GT. Hamster preproglucagon contains the sequence of glucagon and two related peptides. Nature. 1983; 302 716-718.

6 Suda K, Takahashi H, Fukase N, et al. Distribution and molecular forms of glucagon-like peptide in the dog. Life Sci. 1989; 45: 1793-1798.

7 Rouillé Y, Martin S, Steiner DF. Differential processing of proglucagon by the subtilisin-like prohormone convertases PC2 and PC3 to generate either glucagon or glucagon-like peptide. J Biol Chem. 1995; 270: 26 488-26496.

8 Damholt AB, Buchan AM, Holst $\mathrm{JJ}$, et al. Proglucagon processing profile in canine $L$ cells expressing endogenous prohormone convertase $1 / 3$ and prohormone convertase 2. Endocrinology. 1999; 140: 4800-4808

9 Wettergren A, Pridal L, Wøjdemann $\mathrm{M}$, et al. Amidated and non-amidated glucagon-like peptide-1 (GLP-1): non-pancreatic effects (cephalic phase acid secretion) and stability in plasma in humans. Regul Pept 1998; 77: 83-87.

10 Persson K, Gingerich RL, Nayak S, et al. Reduced GLP-1 and insulin responses and glucose intolerance after gastric glucose in GRP receptordeleted mice. Am J Physiol Endocrinol Metab. 2000; 279: E956-E962.

11 Fehmann HC, Göke R, Göke B. Cell and molecular biology of the incretin hormones glucagon-like peptide-l and glucose-dependent insulin releasing polypeptide. Endocr Rev. 1995; 16: 390-410.

12 Meier JJ, Nauck MA, Kranz D, et al. Secretion, degradation, and elimination of glucagon-like peptide 1 and gastric inhibitory polypeptid in patients with chronic renal insufficiency and healthy control subjects. Diabetes. 2004; 53: 654-662.

13 Ørskov C, Wettergren A, Holst JJ. Biological effects and metabolic rates of glucagonlike peptide-1 7-36 amide and glucagonlike peptide-1 7-37 in healthy subjects are indistinguishable. Diabetes. 1993; 42: 658-661.

14 Deacon CF, Nauck MA, Toft-Nielsen M, et al. Both subcutaneously and intravenously administered glucagon-like peptide 1 are rapidly degraded from the NH2-terminus in type 2-diabetic patients and in healthy subjects. Diabetes. 1995; 44: 1126-1131.

15 Duke-Cohan JS, Morimoto C, Rocker JA, et al. Serum high molecula weight dipeptidyl peptidase IV (CD26) is similar to a novel antigen DPPT-L released from activated T cells. J Immunol. 1996; 156: 1714-1721.

16 Ajami K, Abbott CA, Obradovic M, et al. Structural requirements for catalysis, expression, and dimerization in the CD26/DPIV gene family. Biochemistry. 2003; 42: 694-701

17 De Meester I, Durinx C, Bal G, et al. Natural substrates of dipeptidyl peptidase IV. Adv Exp Med Biol. 2000; 477: 67-87.

18 Knudsen LB, Pridal L. Glucagon-like peptide-1-(9-36) amide is a majo metabolite of glucagon-like peptide-1-(7-36) amide after in vivo administration to dogs, and it acts as an antagonist on the pancreatic receptor. Eur J Pharmacol. 1996: 318: 429-435.

19 Hansen L, Deacon CF, Ørskov C, et al. Glucagon-like peptide-1-(7-36) amide is transformed to glucagon-like peptide-1-(9-36)amide by dipeptidy peptidase IV in the capillaries supplying the $L$ cells of the porcine intestine. Endocrinology. 1999; 140: 5356-5363.

20 Mentlein R. Dipeptidyl-peptidase IV (CD26) - role in the inactivation of regulatory peptides. Regul Pept. 1999; 85: 9-24.

21 Wilmen $A$, Walkenbach $A$, Füller $P$, et al. The genomic organization of the human GLP-1 receptor gene. Exp Clin Endocrinol Diabetes. 1998; 106: 299-302.

22 Drucker DJ, Philippe J, Mojsov S, et al. Glucagon-like peptide I stimu lates insulin gene expression and increases cyclic AMP levels in a rat isle cell line. Proc Natl Acad Sci USA. 1987; 84: 3434-3438.

23 Drucker DJ. The biology of incretin hormones. Cell Metab. 2006; 3 $153-165$.

24 Campos RV, Lee YC, Drucker DJ. Divergent tissue-specific and deveopmental expression of receptors for glucagon and glucagon-like peptidein the mouse. Endocrinology. 1994; 134: 2156-2164.

25 Abraham EJ, Leech CA, Lin JC, et al. Insulinotropic hormone glucagon-like peptide-1 differentiation of human pancreatic islet-derived progenito cells into insulin-producing cells. Endocrinology. 2002; 143: 3152-3161.

26 Tourrel C, Bailbé D, Meile MJ, et al. Glucagon-like peptide-1 and exendin-4 stimulate beta-cell neogenesis in streptozotocin-treated newborn rats resulting in persistently improved glucose homeostasis at adult age. Diabetes. 2001; 50: 1562-1570.

27 Li Y, Hansotia T, Yusta B, et al. Glucagon-like peptide-1 receptor signaling modulates beta cell apoptosis. J Biol Chem. 2003 Jan 3; 278: 471-478.

28 Xu G, Stoffers DA, Habener JF, et al. Exendin-4 stimulates both betacell replication and neogenesis, resulting in increased beta-cell mas and improved glucose tolerance in diabetic rats. Diabetes. 1999; 48 : 2270-2276

29 Rolin B, Larsen MO, Gotfredsen CF, et al. The long-acting GLP-1 derivative NN2211 ameliorates glycemia and increases beta-cell mass in diabetic mice. Am J Physiol Endocrinol Metab. 2002: 283: E745-E752.
30 Bregenholt S, Møldrup A, Blume N, et al. The long-acting glucagon-ike peptide-1 analogue, liraglutide, inhibits beta-cell apoptosis in vitro. Biochem Biophys Res Commun. 2005; 330: 577-584.

31 Hui $H$, Nourparvar A, Zhao $X$, et al. Glucagon-like peptide-1 inhibits apoptosis of insulin-secreting cells via a cyclic $5^{\prime}$-adenosine monophosphate-dependent protein kinase $\mathrm{A}$ - and a phosphatidylinosito 3-kinase-dependent pathway. Endocrinology. 2003; 144: 1444-1455.

32 Buteau J, El-Assaad W, Rhodes CJ, et al. Glucagon-like peptide-1 prevents beta cell glucolipotoxicity. Diabetologia. 2004; 47: 806-815.

33 Suarez-Pinzon WL, Power RF, Yan Y, et al. Combination therapy with glucagon-like peptide-1 and gastrin restores normoglycemia in diabetic NOD mice. Diabetes. 2008; 57: 3281-3288.

34 Buteau J. GLP-1 receptor signaling: effects on pancreatic beta-cell proliferation and survival. Diabetes Metab. 2008; 34 Suppl 2: S73-S77.

35 Froud T, Faradji RN, Pileggi A, et al. The use of exenatide in islet transplant recipients with chronic allograft dysfunction: safety, efficacy, and metabolic effects. Transplantation. 2008; 86: 36-45

36 Ghofaili KA, Fung $M, A_{0} Z$, et al. Effect of exenatide on beta cell function after islet transplantation in type 1 diabetes. Transplantation. 2007 83: $24-28$

37 Service GJ, Thompson GB, Service FJ, et al. Hyperinsulinemic hypoglycemia with nesidioblastosis after gastric-bypass surgery. N Engl J Med. 2005; 353: 249-254.

38 Clancy TE, Moore FD Jr, Zinner MJ. Post-gastric bypass hyperinsulinism with nesidioblastosis: subtotal or total pancreatectomy may be needed to prevent recurrent hypoglycemia. J Gastrointest Surg. 2006; 10 1116-1119

39 Vidal J, Nicolau J, Romero F, et al. Long-term effects of Roux-en-Y gastric bypass surgery on plasma GLP-1 and islet function in morbidly obese subjects. J Clin Endocrinol Metab. 2009; 94: 884-891.

40 Faradji RN, Tharavanij T, Messinger S, et al. Long-term insulin independence and improvement in insulin secretion after supplemental islet infusion under exenatide and etanercept. Transplantation. 2008; 86 1658-1665

41 Rickels MR, Mueller R, Markmann JF, Naji A. Effect of glucagon-like peptide- 1 on beta- and alpha-cell function in isolated islet and whole pancreas transplant recipients. J Clin Endocrinol Metab. 2009; 94: 181-189.

42 Rickels MR, Naji A. Exenatide use in islet transplantation: words of caution. Transplantation. 2009; 87: 153.

43 Bojanowska E. Physiology and pathophysiology of glucagon-like peptide-1 (GLP-1): the role of GLP-1 in the pathogenesis of diabetes melltus, obesity, and stress. Med Sci Monit. 2005; 11: RA271-RA278.

44 Greig NH, Mattson MP, Perry T, et al. New therapeutic strategies and drug candidates for neurodegenerative diseases: p53 and TNF-alpha inhibitors, and GLP-1 receptor agonists. Ann N Y Acad Sci. 2004; 1035 290-315.

45 Perry T, Lahiri DK, Sambamurti K, et al. Glucagon-like peptide-1 decreases endogenous amyloid-beta peptide (Abeta) levels and protects hippocampal neurons from death induced by Abeta and iron. J Neurosci Res. 2003; 72: 603-612.

46 Perry T, Greig NH. A new Alzheimer's disease interventive strategy: GLP-1. Curr Drug Targets. 2004; 5: 565-571.

47 Gilman CP, Perry T, Furukawa K, et al. Glucagon-like peptide 1 modulates calcium responses to glutamate and membrane depolarization in hippocampal neurons. J Neurochem. 2003; 87: 1137-1144.

48 Perry T, Holloway HW, Weerasuriya A, et al. Evidence of GLP-1-mediated neuroprotection in an animal model of pyridoxine-induced peripheral sensory. Exp Neurol. 2007; 203: 293-301.

49 During MJ, Cao L, Zuzga DS, et al. Glucagon-like peptide-1 receptor is involved in learning and neuroproection. Nat Med. 2003; 9: 1173-1179.

50 Geelhoed-Duijvestijn PH. Incretins: a new treatment option for type 2 diabetes? J Med. 2007; 65: 60-64.

51 MacLusky NJ, Cook S, Scrocchi, et al. Neuroendocrine function and response to stress in mice with complete disruption of glucagon-like peptide-1 receptor signaling. Endocrinology. 2000; 141: 752-762.

52 Turton MD, 0'Shea D, Gunn I, et al. A role for glucagon-like peptide-1 in the central regulation of feeding. Nature. 1996; 379: 69-72.

53 Gonzalez C, Beruto V, Keller G, et al. Investigational treatments for 2 diabetes mellitus: exenatide and liraglutide. Expert Opin Investig Drugs. 2006; 15: 887-895.

54 Abbott CR, Monteiro M, Small CJ et al. The inhibitory effects of peripheral administration of peptide $\mathrm{YY}(3-36)$ and glucagon-like peptide-1 on food intake are attenuated by ablation of the vagal-brainstem-hypothalamic pathway. Brain Res. 2005; 1044: 127-131.

55 Abbott CR, Small CJ, Sajedi A, et al. The importance of acclimatisation and habituation to experimental conditions when investigating the anorectic effects of gastrointestinal hormones in the rat. Int J Obes. 2006 30: 288-292.

56 Tachibana T, Oikawa D, Adachi N, et al. Intracerebroventricular injection of glucagon-like peptide-1 changes lipid metabolism in chicks. Comp Biochem Physiol A Mol Integr Physiol. 2007; 147: 1104-1108. 
57 Osaka T, Endo M, Yamakawa M, et al. Energy expenditure by intravenous administration of glucagon-like peptide- 1 mediated by lower brainstem and sympathoadrenal system. Peptides. 2005; 26: 1623-1631.

58 Knauf C, Cani PD, Perrin C, et al. Brain glucagon-like peptide-1 increases insulin secretion and muscle insulin resistance to favor hepatic glycogen storage. J Clin Invest. 2005; 115: 3554-3563.

59 Ayala JE, Bracy DP, James FD, et al. The glucagon-like peptide-1 re ceptor regulates endogenous glucose production and muscle glucose uptake independent of its increatin action. Endocrinology. 2009; 150: $1155-1164$

60 Nogueiras R, Perez-Tilve D, Veyrat-Durebex $C$, et al. Direct contro of peripheral lipid deposition by CNS GLP-1 receptor signaling is mediated by the sympathetic nervous system and blunted in diet-induced obesity. J. Neurosci. 2009; 29: 5916-5925.

61 Fujita $Y$, Wideman RD, Speck $M$, et al. Incretin release from gut is acutely enhanced by sugar but not by sweeteners in vivo. Am J Physio Endocrinol Metab. 2009; 296: E473-E479.

62 Kokrashvili Z, Mosinger B, Margolskee RF. Taste signaling elements expressed in gut enteroendocrine cells regulate nutrient-responsive secretion of gut hormones. Am J Clin Nutr. 2009; 90: 822S-825S.

63 Neary NM, Small CJ, Druce MR. Peptide YY 3-36 and glucagon-like peptide-17-36 inhibit food intake additively. Endocrinology. 2005; 146: 5120-5127.

64 Greenfield JR, Farooqi IS, Keogh JM, et al. Oral glutamine increases circulating glucagon-like peptide-1, glucagon, and insulin concentrations in lean, obese, and type 2 diabetes subjects. Am J Clin Nutr. 2009; 89 106-113.

65 Tessari P, Kiwanuka E, Cristini M. Slow versus fast proteins in the stimulation of beta-cell response and the activation of the entero-insular axis in type 2 diabetes. Diabetes Metab Res Rev. 2007; 23: 378-385.

66 Flint A, Raben A, Astrup A, et al. Glucagon-like peptide-1 promotes satiety and suppresses energy intake in humans. J Clin Invest. 1998; 101 515-520.

67 Verdich C, Flint A, Gutzwiller JP, et al. A meta-analysis of the effect of glucagon like peptide-1 (7-36) amide on ad libitum energy intake in humans. J Clin Endocrinol Metab. 2001; 86: 4382-4389.

68 Zander M, Madsbad S, Madsen JL, Holst JJ. Effect of 6-week course of glucagon like peptide-1 on glycaemic control, insulin sensitivity and beta-cell function in type 2 diabetes: a parallel-group study. Lancet. 2002 359: 824-830.

69 Naslund E, King N, Mansten S, et al. Prandial subcutaneous injections of glucagon-like peptide- 1 cause weight loss in obese human subjects. B J Nutr. 2004; 91: 439-446.

70 Neary MT, Batterham RL. Gut hormones: implications for the treat ment of obesity. Pharmacol Ther. 2009; 124: 44-56.

71 Ranganath LR, Beety JM, Morgan LM, et al. Attenuated GLP-1 secretion in obesity: cause or consequence? Gut. 1996; 38: 916-919.

72 Lugari L, Dei Cas A, Ugolotti D, et al. Glucagon-like peptide-1 (GLP-1) secretion and plasma dipeptidyl peptidase IV (DPP-IV) activity in morbicly obese patients undergoing biliopancreatic diversion. Horm Metab Res. 2004; 36: 111-115.

73 Camilleri M. Peripheral mechanisms in the control of appetite and related experimental therapies in obesity. Regul Pept. 2009; 156: 24-27.

74 Moran TH, Dailey MJ. Minireview: gut peptides: targets for antiobesity drug development? Endocrinology. 2009; 150: 2526-2530.

75 Wideman RD, Kieffer TJ. Mining incretin hormone pathways for novel therapies. Trends Endocrinol Metab. 2009; 20: 280-286.

76 Le Roux CW, Welbourn R, Werling M, et al. Gut hormones as mediators of appetite and weight loss after Roux-en-Y gastric bypass. Ann Surg 2007; 246: 780-785.

77 De Luis DA, Gonzalez Sagrado M, Conde R, et al. Decreased basal levels of glucagon-like peptide-1 after weight loss in obese subjects. Ann Nut Metab. 2007: 51: 134-138.

78 Burcelin R. The incretins: a link between nutrients and well-being. $B$ J Nutr. 2005; 93 Suppl 1: S147-S156.

79 Chaudhri OB, Wynne K, Bloom SR. Can Gut hormones control appetite and prezent obesity? Diabetes Care. 2008; 31 Suppl 2: S284-S289.

80 Ahloulay M, Dechaux M, Laborde K, et al. Influence of glucagon on GFR and on urea and electrolyte excretion: direct and indirect effect. Am J Physiol. 1995; 269: F225-F235.

81 Gutzwiller JP, Tschopp S, Bock A, et al. Glucagon-like peptide 1 induces natriuresis in healthy subjects and in insulin-resistant obese men. $\mathrm{J}$ Clin Endocrinol Metabol. 2004; 89: 3055-3061.

82 Gutzwiller JP, Hruz P, Huber AR, et al. Glucagon-like peptide 1 is involved in sodium and water homeostasis in humans. Digestion. 2006; 73 $142-150$

83 Moreno C, Mistry M, Roman RJ. Renal effects of glucagon-like pep tide in rats. Eur J Pharmacol. 2002; 434: 163-167.

84 Yu M, Moreno C, Hoagland KM, et al. Antihypertensive effect of glucagon-like peptide 1 in Dahl salt-sensitive rats. J Hypertens. 2003 21: $1125-1135$
85 Garber A, Henry R, Ratner R, et al. Liraglutide versus glimepirde monotherapy for type 2 diabetes (LEAD-3 Mono): a randomised, 52 -week, phase III, double-blind, parallel-treatment trial. Lancet. 2009; 373 $473-481$

86 Richter G, Feddersen 0, Wagner U, et al. GLP-1 stimulates secretion of macromolecules from airways and relaxes pulmonary artery. Am J Phys iol Lung Cell Mol Physiol. 1993; 265: L374-L381.

87 Nystrom T, Gutniak MK, Zhang 0 , et al. Effects of glucagon-like peptide-1 on endothelial function in type 2 diabetes patients with stable coronary artery disease. Am J Physiol Endocrinol Metab. 2004; 287 E1209-E1215

88 Ban K, Noyan-Ashraf MH, Hoefer J, et al. Cardioprotective and vasodilatory actions of glucagon-like peptide 1 receptor are mediated through both glucagon-like peptide 1 receptor-dependent and -independent pathways. Circulation. 2008; 117: 2340-2350.

89 Bose AK, Mocanu MM, Carr RD, et al. Glucagon-like peptide 1 can directly protect the heart against ischemia/reperfusion injury. Diabetes. 2005 54: $146-151$

90 Nikolaidis LA, Mankad S, Sokos GG, et al. Effects of glucagon-like peptide-1 in patients with acute myocardial infarction and left ventricula dysfunction after successful reperfusion. Circulation. 2004; 109: 962-965.

91 Bose AK, Mocanu MM, Carr RD, et al. Myocardial ischaemia-reperfusion injury is attenuated by intact glucagon like peptide-1 (GLP-1) in the in vitro rat heart and may involve the p70s6K pathway. Cardiovasc Drugs Ther. 2007; 21: 253-256.

92 Tuunanen $\mathrm{H}$, Engblom E, Naum A, et al. Trimetazidine, a metabolic modulator, has cardiac and extracardiac benefits in idiopathic dilated cardiomyopathy. Circulation. 2008; 118: 1250-1258.

93 Taegtmeyer $\mathrm{H}$, Golfman L, Sharma S, et al. Linking gene expression to function: metabolic flexibility in the normal and diseased heart. Ann N Y Acad Sci. 2004; 1015: 202-213.

94 Kavianipour M, Ehlers MR, Malmberg K, et al. Glucagon-like peptide(7-36) amide prevents the accumulation of pyruvate and lactate in the ischemic and non-ischemic porcine myocardium. Peptides. 2003; 24: 569-578. 95 Luque MA, González N, Márquez L, et al. Glucagon-like peptide(GLP-1) and glucose metabolism in human myocytes. J Endocrinol. 2002 173: $465-473$

96 Zhao T, Parikh P, Bhashyam S, e al. Direct effects of glucagon-like peptide-1 on myocardial contractility and glucose uptake in norma and postischemic isolated rat hearts. J Pharmacol Exp Ther. 2006; 317 1106-1113.

97 Nikolaidis LA, Elahi D, Hentosz T, et al. Recombinant glucagon-like peptide-1 increases myocardial glucose uptake and improves left ventricular performance in conscious dogs with pacing-induced dilated cardiomyopathy. Circulation. 2004; 110: 955-961

98 Nikolaidis LA, Elahi D, Shen YT, et al. Active metabolite of GLP-1 mediates myocardial glucose uptake and improves left ventricular performance in conscious dogs with dilated cardiomyopathy. Am J Physiol Heart Circ Physiol. 2005; 289: H2401-H2408.

99 Poornima I, Brown SB, Bhashyam S, et al. Chronic glucagon-like peptide-1 infusion sustains left ventricular systolic function and prolongs survival in the spontaneously hypertensive, heart failure-prone rat. Circ Heart Fail. 2008; 1: 153-160.

100 Sokos GG, Nikolaidis LA, Mankad S, et al. Glucagon-like peptide-1 in fusion improves left ventricular ejection fraction and functional status in patients with chronic heart failure. J Card Fail. 2006; 12: 694-699.

101 Sokos GG, Bolukoglu H, German J, et al. Effect of glucagon-like peptide-1 (GLP-1) on glycemic control and left ventricular function in patients undergoing coronary artery bypass grafting. Am J Cardiol. 2007; 100: $824-829$ 


\title{
Rola glukagonopodobnego peptydu 1 w homeostazie glukozy oraz innych aspektach fizjologii człowieka
}

\author{
Edward Franek ${ }^{1,2}$, Grzegorz Gajos ${ }^{3,4}$, Janusz Gumprecht ${ }^{5}$, Adam Krętowski ${ }^{6}$, \\ Barbara Zahorska-Markiewicz ${ }^{7}$, Maciej T. Małecki ${ }^{8}$ \\ 1 Klinika Chorób Wewnętrznych, Endokrynologii i Diabetologii, Centralny Szpital Kliniczny, MSWiA, Warszawa \\ 2 Zakład Badawczo-Leczniczy Endokrynologii, Instytut Medycyny Doświadczalnej i Klinicznej im. M. Mossakowskiego, Polska Akademia Nauk, Warszawa \\ 3 Klinika Choroby Wieńcowej, Instytut Kardiologii, Uniwersytet Jagielloński, Collegium Medicum, Kraków \\ 4 Krakowski Szpital Specjalistyczny im. Jana Pawła II, Kraków \\ 5 Katedra i Klinika Chorób Wewnętrznych i Diabetologii i Nefrologii, Śląski Uniwersytet Medyczny, Zabrze \\ 6 Klinika Endokrynologii, Diabetologii i Chorób Wewnętrznych, Uniwersytet Medyczny w Białymstoku, Białystok \\ 7 NZOZ Poradnia Leczenia Chorób Metabolicznych WAGA, Katowice \\ 8 Katedra i Klinika Chorób Metabolicznych, Uniwersytet Jagielloński, Collegium Medicum, Kraków
}

\section{SŁOWA KLUCZOWE}

GLP-1, hormony jelitowe, oś inkretynowa, wydzielanie insuliny

\section{STRESZCZENIE}

W niniejszej pracy przedstawiono strukturę, funkcję i patofizjologię glukagonopodobnego peptydu 1 (glucagon-like peptide 1 - GLP-1). Opisano fizjologię i patofizjologię osi inkretynowej, w której skład wchodzi GLP-1, a także omówiono biosyntezę, wydzielanie, działanie i degradację tego hormonu jelitowego. Przedstawiono także działanie GLP-1 na część wewnątrzwydzielniczą trzustki, układ sercowo-naczyniowy, ośrodkowy układ nerwowy oraz gospodarkę wodno-elektrolitową. 